\title{
The Growing Threat of Money Laundering to Vietnam:
}

\section{The Necessary of Intensive Countermeasures}

\author{
Chat Le Nguyen \\ School of Law, University of Canterbury, New Zealand
}

\begin{abstract}
Purpose - The paper sketches out the scenario of money laundering (ML) in Vietnam and the harm ML may cause to the country.

Design/methodology/approach - This paper first, based on the general concept of ML, scrutinizes actual and potential ML in Vietnam as well as ML threat to Vietnam. The typical cases of predicate offences, which were associated with ML activity, will be provided to illustrate the fact. Then a brief of Vietnam's response to ML will be examined.

Findings - ML has actually occurred since early in Vietnam. The potential for ML in Vietnam is substantial and poses growing harm to Vietnam in both the respects of economy and security. Although Vietnam has the primary legal framework of AML and set out AML countermeasures, the implementation has been hindered by several factors.
\end{abstract}

Originality/value - This paper would attract the attention of people who are concerned about ML in Vietnam.

Keywords Money laundering, Vietnam

Paper type General review

\section{Introduction}

The geographical, economical and legal background of Vietnam creates several unique attributes that make it an attractive destination of tainted money. For instance, Vietnam is a largely cash-based economy surrounded by other neighbouring cash-based countries (Cambodia, Laos and China). Cash is easily exchanged and moved through a long 
Vietnamese border. In addition, being one of the fastest emerging economies in the Southeast Asian region with lax legal system is another facilitator of ML. Vietnamese competent authorities, however, have not yet conducted any comprehensive research about actual ML, its typologies and its threat to Vietnam. The threat of ML to Vietnam appears not to be weighed appropriately.

This paper will deal with the primary questions: How is the extent of ML in Vietnam and its threat to Vietnam? And why does Vietnam need to more intensively respond to ML?

\section{An overview of money laundering in Vietnam}

\subsection{Conception of $M L$}

It is noteworthy that the academic definition of ML remains to be elusive; however, ML can be identified and distinguished clearly from other illegal activities by its main purposes.

The term "money laundering" is considered to have been originally used by American police in the 1920s in the United State with reference to Al Capone and other Chicago gangsters (Lilley, 2006, p. 5). It is also argued to have first appeared in connection with the Watergate scandal in the United State in 1973 (Jeffrey, 1997, pp. 6-9). Nevertheless, there is robust evidence that it was used as a legal meaning in the 1980s to describe the process of transforming the drug trafficking proceeds into legitimate capital (Stessens, 2000, p. 82). It has been used extensively as a legal term in relevant legislation and legal text ever since. In 1985, a formal definition was given by the American President's Commission on Organized Crime:

\footnotetext{
"Money laundering is the process by which one conceals the existence, illegal source, or illegal application of income, and then disguises that income to make it appear legitimate" (President's Commission on Organized Crime (the United States), 2001, p. 7).
}

Following this definition, many academics, professionals, and organizations defined and clarified the phenomenon of ML in their own words. For example: 


\begin{abstract}
"Money laundering is the conversion of illicit cash to another asset, the concealment of the true source of ownership of the illegally acquired proceeds, and the creation of the perception of legitimacy of source and ownership" (Gilmore, 1992, p. x).
\end{abstract}

"Money laundering is an activity aimed at concealing the unlawful source of sums of money" (Savona, 2000, p. 6).

In these definitions, the term "proceeds" is used to refer to any property derived from or obtained, directly or indirectly, through the commission of the criminal activities. These properties may be purchased with and traceable to criminal profit. The term "proceeds" has been used and distinguished from "profit" of crime in US legislation since early 1980s (Fried, 1988, pp. 374-75). Then, it has associated with the definition of ML since its first legal definition in the United Nations Convention against Illicit Traffic in Narcotic Drugs and Psychotropic Substances (1988).

\footnotetext{
"Proceeds" means any property derived from or obtained, directly or indirectly, through the commission of an offence established in accordance with article 3, paragraph 1 of this convention (United Nations, 1988)
}

Though these authors differ in their terms and approaches, they all allude that the main purposes of ML are to conceal and acquire an apparently legal source for illegal proceeds gained by underlying criminal offences (predicate offences). Criminals engage in ML in order to ensure the secure ownership of the proceeds as their lifeblood, and to shield the proceeds from suspicion, investigation and seizure. In order to obtain these purposes, highly sophisticated ML process has been developed which is usually described as having three major sequential stages: placement, layering and integration (Gilmore, 1999). Not all ML processes involve all these three stages, some may involve more and some less (Duyne and Levi, 2005, pp. 152-55). These stages can be separate and distinct, but more often some of them are conducted simultaneously or overlap (Hopton, 2006, p. 2). A variety of mechanism and typologies may be deployed in ML operation; for example through currency, gold, precious metals and precious stones smuggling, banking sector, Alternative Remittance System (ARS), stock market and trade-based ML (He, 2010). 


\subsection{Sources of illicit fund and associated ML activities}

According to the conception of ML, there is no ML without predicate offences which often generate enormous illicit funds. The problem of ML should be examined with reference to the issue of predicate offences as well as sources of illegal funds. In Vietnam, the predicate offences, that are normally associated with ML activities, encompass drug-related crimes, organized crimes, public corruption, trafficking in persons and other crimes related to illegal gambling, prostitution or counterfeiting of goods. Remittances from the proceeds of crime committed abroad, such as narcotics trafficking in Australia, Canada and the United States are a part of illicit funds. Popular typologies of ML are recognized as through remittance system, banking sector, real estate market, trade-based ML, and stock market.

\section{a) Drug-related crimes}

Vietnam's geographic location and insufficient capacity in countering drug trafficking are the striking facilitators that make Vietnam as an attractive transit site for drug traffickers to smuggle drug productions from Golden Triangle to Australia, the United State, Canada and European countries (U.S. Department of State, 2011, p. 582). In the same time, Vietnam is a prospective consumption market of drug productions with ever growing number of drug users in recent decade (U.S. Department of State, 2011, p. 584). Drug-related crimes have increased at a high rate in the recent years. Significant part of a huge profit generated from drug-related crimes was believed to be laundered in Vietnam by diverse typologies.

\section{Case 1:}

In January 2007, the People's Court of northern Son La province handed down seven death sentences in the case of "Trinh Nguyen Thuy and his accomplices in conspiracy of drug trafficking" (affirmed in appeal court) (TTXVN, 2010). Thuy and his accomplices were found guilty of various charges related to illegally trading of heroin and opium, and producing heroin. This case is known as one of the largest drug-related cases ever brought by Vietnamese courts. This case is notorious for its number of death sentences, huge amount of trading heroin and opium, bribing high-ranking public officials, and especially for link to an elaborate ML scheme. The investigation revealed that after roughly 20 years involving drug 
trafficking, Thuy gained tremendous profit which then was mainly invested in real estate. At the time of being arrested in 2005, Thuy was the Chairman of Board of a joint stock company and director of a front company. By bribing officials in the Ministry of Agriculture and Rural Development (Vietnam), his companies were granted a number of well-known real estate projects in Hanoi that helped him to cover his underlying criminal activities and legalize criminal proceeds derived from the crimes. Further, he also owned several private real properties and luxurious cars. Nevertheless, he and his accomplices were not investigated or accused of any charge in relation to ML. Only a few his private properties which were proved criminal origin were confiscated.

\section{b) Organized crimes}

Though the formal definition of organized crime has not provided in Vietnamese laws, the phenomenon of organized crime and its features have been figured out by either Vietnamese law enforcement authorities or experts. Since early the 2000s, following the crackdown on a number of notorious organized crime gangs, the terms 'black society'-style organized crime ('toi pham hoat dong theo kieu xa hoi den') and mafia-style crime are used widely to describe a serious organized criminal group (Thanh, 2012). 'Black society'-style organized crimes are recognized as close-knit gangs associated with armed robbery, racketeering, smuggling, drug trafficking, prostitution, illegal gambling and even contract murder. In addition, mafia-style crime is highly potential in Vietnam (Chau, 2011). Beyond the characteristics of 'black society'-style organized crime, mafia-style crime is characterized by further elements: wellorganized in its structure and operation, possessing certain economic strength gained through illegal activities, enjoying protection from public officials through bribery and threat, and causing serious harm to society. Mafia-style crime often engages with potential lucratively business to cover their criminal activities, launders its proceeds and makes more profits. Criminal profit generated by organized crime is normally used to buy real property, establish entertainment business (e.g. restaurants, hotels and discos), invest in front companies; or is transferred overseas to launder.

\section{Case 2:}


In 2003, the extraordinary trial of 'Nam Cam' case with 155 defendants, which is the biggest case in the history of criminal procedure in Vietnam, shocked the Vietnamese public and seized a great deal attention of domestic and foreign media (Gillespie, 2005, pp. 201-02). After more than 3 months of hearing, the Ho Chi Minh City People's Court imposed the death penalty on southern mafia-style crime boss Truong Van Cam, better known as nickname 'Nam Cam', and five of his associates (one death penalty on his accomplice was dropped in appeal court). 'Nam Cam' was found guilty of numerous charges including murder, bribery and organized illegal gambling. Sixteen officials, including two members of the Communist Party's powerful Central Committee and several high-ranking police officers, were imprisoned. The indictment indicated that 'Nam Cam' amassed a fortune during a decade at the top of an underground criminal network of gambling dens, loan sharks, protection rackets and prostitution rings. His web spread from its Ho Chi Minh base to other southern provinces and the capital Hanoi, attracted partners from Taiwan and Cambodia. It was predicted that at the time of being arrested, 'Nam Cam' raked in about US\$2 million per month from the protection of hundreds of restaurants, discos illegal gambling clubs (Johnson, 2003). Nevertheless, when the police carried out a thorough search of his private houses, only VND750 million (about US\$37,000) was found. The investigation unveiled that his huge criminal proceeds were primarily invested in several famous restaurants and discos in Ho Chi Minh City, buying real property, bribery, and are transferred abroad. His legal businesses made him known as a successful businessman in Ho Chi Minh City's entertainment industry. After the trial, it was extremely difficult for the competent authority to determine, trace and locate the illegal root of his property. Thus, there was no conviction for ML, and the appeal court finally ordered to confiscate only a small part of his private property (PV, 2003).

\section{c) Corruption}

In 2012, Transparency International's Corruption Perceptions Index ranked Vietnam $123^{\text {rd }}$ out of 174 nations (perceived level of public-sector corruption) (Transparancy International, 2012). Corruption occurs systematically at all levels and in all sectors, ranging from administrative, political, and judicial sector in Vietnam (WB, 2013). Both Vietnamese politician leaders and public have realised that corruption is a major threat to the leadership of the Communist Party and social stability. The Communist Party of Vietnam (CPV) and the 
Government, recently, have taken intensive action to demonstrate their strong willingness to prevent and suppress corruption. Over the past ten years, the CPV, the National Assembly and the Government of Vietnam have issued various anti-corruption related documents. The crimes of corruption have been regulated in the 1999 Penal Code (National Assembly, 1999) from Articles 278-284; the Law on Prevention and Suppression of Corruption was promulgated in 2005 (National Assembly, 2005); and Vietnam has become a Party of the United Nations Convention against Corruption (UNCAC) in 2009 (United Nations, 2003). However, the public has shown scepticism about the effective implementation of these legal instruments. Corruption is still increasing with more sophistication and extensive scope that result in more serious effect on Vietnamese economy and society. During the 1990s, the corruption cases such as Tamexco (1996) (Gainsborough, 2003, pp. 74-80) and Tang Minh Phung (1997) (Gillespie, 2001, pp. 13-21), which caused the considerable losses to the society, were described as big corruption scandals at that time with the involvement of several senior public officials. In the 2000s, the extent of other cases, such as Vinapco (2004), PMU 18 (2006) (WB, 2010), PCI (2008) (Sato, 2009, pp. 222-23), “Southern Services Flight Company, Petro Vietnam Gas Company, Vietsovpetro Joint Venture, and T \&T Co. Ltd. I Nexus Technologies" (US, 2010), is much greater with huge money and sophisticated methods in bribery.

It is evident that corruption and money laundering are related and self-reinforcing phenomena. Corruption proceeds are disguised and laundered by corrupt officials to be able to spend or invest such proceeds. At the same time, corruption in a country's AML institutions (including financial institutional regulators, police, prosecutors, and courts) can render the implementation of AML countermeasures (WB, 2007 ). Corrupt officials may launder the proceeds of corruption by various methods (FATF, 2011). With the massive corruption in Vietnam, there is no doubt that ML related to the proceeds of corruption is substantial.

\section{Case 3:}

In May 2008, the Hanoi People's Court presided the first hearing of the Vinapco case that relates to a massive scam and corruption scandal happened in the state-owned company (Viet Nam Air Petrol Company (Vinapco)) from 1996 to 2003 (Linh, 2008). Because of the complexity that requires further investigation and cross-examination hundreds of witnesses, the last judgement of this case has yet issued. According to police's investigation, prosecutor's indictment and a preliminary report released by the State Inspector, Vinapco lost 
VND243 billion ( equivalent US\$15.4 million) in fuel trading between 1999 and 2003 (AFP, 2004). The police said it was unprecedented for so many top officials complicit in a scam to embezzle a huge amount of public funds. It is noteworthy that the defendants conspired to establish their own joint stock company (Nam Vinh Joint Stock Company) as a front company to make a legitimate appearance of the illicit money derived from corruption (SGGP, 2005). However, charge of ML was not considered.

\section{d) Proceeds of crime committed abroad}

The proceeds of predicate crimes committed abroad can be transferred to Vietnam via formal financial system (e.g. banks) or alternative remitters. These proceeds can be integrated into the Vietnamese economy in form of foreign capital investment or remittance.

In recent decade, Vietnam has become one of the fastest emerging economies in the Southeast Asian region. The adoption of the Doi Moi (reform policy) in 1986 has initiated the transition of country from a centrally-planned to market-based economy. The economic reform accompanied with other merits, such as geographical location and human resource, have promoted Vietnam as an attractive destination of foreign investment. Moreover, like other transitional countries which are undergoing economic reform, Vietnam has a strong need of funds from abroad for its development. The Government has adopted and changed their policies as well as legislation with the aim of attracting more overseas investment, facilitating businesses, and integrating into the global economy. Since the early 2000s, Vietnam has witnessed an extraordinary wave of foreign investment in form of Foreign Direct Investment (FDI) or indirect investment (e.g. through the new-established stock market). There is, in the same time, a rapid growth of stock markets and the large-scale privation of public enterprises. Money launderers can utilize this situation to launder the illegal proceeds generated overseas.

Additionally, in the recent years, Vietnam has been always among the world's top recipients of remittances. In 2010, Vietnam is the world's tenth biggest recipient of officially recorded remittances among developing countries with about US\$7,2 billion (WB, 2011). The remittance contributes considerably to the Vietnamese economy. However, a part of the proceeds of crimes (e.g. drug trafficking) committed by Vietnamese people living abroad (particularly in Australia, Canada and the United States) may be transferred to Vietnam in form of remittance. A remittance service may be abused for transferring tainted money from abroad to Vietnam[1]. 


\section{Case 4:}

In March 2004, more than 130 defendants across the United States and Canada were arrested as part of a three-year investigation, called "Operation Candy Box", that targeted at an international criminal organization involved in illegal drug producing, drug trafficking and ML (U.S, 2004). According to the result of collaborative investigation among several American and Canadian law enforcement agencies, the organization was controlled by $\mathrm{Ze}$ Wei Wong, a Chinese national, and Mai Phuong Le, a Vietnamese immigrant holding Canadian citizen. Ze Wei Wong was alleged to be the leader of a drug contribution ring operating in 18 US cities and Canada; while Le was accused of directing the ML sophisticated operation through money remitters and travel agencies in both the U.S. and Canada. It was proved that up to a million Ecstasy tablets was delivered per month and as much as US\$5 million of illicit proceeds was transferred to abroad (including Vietnam) per month over five years.

In 2009 and 2011, at Dong's trial (U.S. v. Dong Dang Huynh, 2011), the evidence demonstrated that Dong (a US citizen living in the U.S.) and Mai Phuong Le (a Canadian citizen living in Canada) conspired to launder money generated from drug trafficking through US Tours and Remittance (US Tours) founded by Dong which did business as both a travel agency and a money remittance service to Vietnam. The funds in US Tours' bank account were transferred a few times a week to the account of a business in Vietnam run by Dong's brother. Dong was found guilty of ML, conspiracy to commit ML, and conspiracy to defraud the United States by failing to file currency transaction reports (CTR).

It is noticeable that in January 2004, Mai Phuong Le and the representatives of Viet-Can Resort \& Plantation Incorporation (a Canadian company) travelled to Khanh Hoa province and Ho Chi Minh City (Vietnam) to seek "investment project" and business partners (Thuc, 2007). At the very welcome meeting and discussion with leaders of Khanh Hoa province, she and her company were recommended as the most successful Vietnamese business in Canada and wanted to invest at least US\$25 million in the real estate projects (building resort and rented-apartments) in Khanh Hoa. In February, after one month arriving in Vietnam, the project that may help her launder millions US\$ was promptly approved. Unfortunately, with the cooperation of the Interpol of Vietnam, she was arrested in Canada before she can carry out the project. 
The increasing extent of above-mentioned predicate offences accompanied with other facilitators of ML, such as cash-based dominant economy, insufficient capacity and legal framework in countering ML (APG, 2009), foster ML in Vietnam. Despite no specific and concrete statistic about ML in Vietnam, ML has, undoubtedly, occurred considerably in the country and caused certain harms.

\section{The threat of money laundering and Vietnam's response}

\subsection{The threat of money laundering to Vietnam}

It has been revealed the ML poses an intrinsic potential harm to not only economic aspect but political system and social security at both global and national level (FATF, 2010). ML may undermine the legitimate economies and foster the increase of organized crimes. ML contributes to the economic and political influence of criminal organizations on the society that threatens national security, sovereignty of States and social well-being (Alldridge, 2008, p. 449). Being a developing country in the transitional period, Vietnam may be more vulnerable to ML threat than others.

\section{ML threat to economic aspect}

First, ML may undermine the integrity of financial institutions.

Money launderers often abuse financial institutions, including banks and non-banking institutions for their operations. The fraudulent activities conducted by money launderers or corrupt individuals within these institutions may result in the increase of operational risk reputational risk (Bartlett, 2002, p. 5). Further, the proceeds of crime flowing in financial institutions may also lead to liquidity risk (a shortfall in resources to meet obligations). For example, a huge amount of laundered fund may arrive at a bank, and then disappear without notice in response to non-market factors. This unavoidably affects the bank's operation and its liquidity. These risks would be likely more serious for the Vietnamese financial institutions, which are often weak in managing their assets, liabilities and operations.

Second, ML may depress productivity and distort the fair competition.

The proceeds of crime can be introduced into the legitimate economy as a legal investment capital in business ventures or buying luxury commodities. However, this investment, known as "sterile investment", is for purpose of laundering criminal proceeds rather than maximizing the profit of enterprises, or generating additional productivity to 
society as well. Buying real properties and luxury consumption assets are the foremost option of money launderers in Vietnam.

Money launderers, in addition, often use front companies for commingling the proceeds of crime with legitimate capital. The "sterile" investment allows these companies to provide products or services below market rates. This distorts a fair competition in legitimate market. Thus, the legitimate investment and business sector are susceptible to ML.

Third, ML may result in loss of economic policy control.

An enormous amount of laundered money flowing in the small national economy, like Vietnam, may cause inexplicable change in money demand, volatility of capital flows, misallocation of resources, and artificial distortion in commodity prices (McDowell et al., 2001, p. 3). This can contribute to the instability of monetary policy and commodity price, for example the instable exchange rate, instable interest rate, or inflation. In addition, the misleading information about money transaction given to policymakers may lead to the inaccurate economic management that causes the macroeconomic instability.

ML may pose other possible negative economic effects, such as loss of tax revenue and risks to privatization of state-owned enterprises in Vietnam on the way of economic reform.

\section{ML threat to state security and political system}

Obviously, there is an extricable link between ML and the underlying criminal activities that generate illicit proceeds. ML fuels these criminals by protecting their proceeds. Successful ML helps criminals enjoy their proceeds which may encourage them to commit further crimes. The fact that criminals can convert, conceal or disguise easily their illicit proceeds in Vietnam is one of the stimuli to ever-growing organized crime and corruption recently. The rise of these kinds of crime, especially drug trafficking, human trafficking, and mafia-style crimes is a great danger to state security.

Further, the consolidation of economic power of criminal organizations enables them to penetrate the legitimate economy, law enforcement agencies and political system. Money launderers often use bribery in critical gateways, such as enforcement agencies and legislatures to make ML successful. This rewards corruption and erodes the integrity of law enforcement agencies. In turn, because of massive corruption and spread of organized crime, the scale of ML is unavoidably being extended. 


\subsection{Vietnam's response to money laundering}

Vietnam has taken several steps towards establishing and improving its Anti -Money Laundering (AML) regime in accordance with international standards.

In 1999, although the term of "money laundering" was not defined and used in any formal legal documents, a number of activities, which are actually ML activities, were first criminalized in Article 250 and 251 of the 1999 Penal Code of Vietnam[2]. In 2005, the term "money laundering" ("rua tien") and the general legal framework of AML in Vietnam were first stipulated in the Governmental Decree No. 74/ 2005/ND-CP[3]. In May 2007, Vietnam joined the Asia/Pacific Group on Money Laundering (APG). Furthermore, the crime of ML ("toi rua tien") is criminalized as an independent offence in article 34(1) of the amendment to the 1999 Penal Code (2009) of Vietnam[4]. The Law on Prevention and Suppression of Money Laundering was passed by National Assembly of Vietnam in June 2012, and take effect in January 2013 (National Assembly, 2012). Other AML legal regulations are scattered in various domestic laws.

Under the mutual evaluation of the international organizations, such as the APG (APG, 2009) and Financial Action Task Force (FATF), Vietnam has not made sufficient progress in implementing its AML legal framework. Certain strategic AML deficiencies remain(FATF, 2012). The Vietnamese authorities argue that these evaluations is partly unreasonable; and that because of ambiguous wording in Vietnamese laws, there are some misunderstandings of the Vietnamese AML legal regulations (APG, 2009, pp. 213-19). However, as can be seen from the above-described cases, and a low number of convictions for ML shows that the implementation of AML legal framework is not effective[5]. Investigators and prosecutors tend to focus on the primary crime, which is the predicate crime, rather than its proceeds. They generally have not been yet willing to investigate and refer ML as a separate charge; or to locate, seize and confiscate illegal proceeds. There are various reasons for the reluctance and the lack of voluntary (Croissant, 2007, pp. 144-49). One of the reasons can be that Vietnam authorities have not weighed properly the harm ML may cause to the society.

\section{Conclusion}

A variety of attributes have made Vietnam highly vulnerable to ML, including transnational ML. Though ML is an on-going phenomenon which poses a real growing threat 
and can cause ultimate harms to Vietnam's economy as well as security, ML and its threat seem to be new concerns in Vietnam. Being a transitional and fragile economy, Vietnam's economy should be more vigilant at ML. Vietnamese authorities and public should have deeper perception of actual and potential ML as well its growing threat to the society.

The harm of ML may be difficult to examine in short term, but in long run, it is undoubtedly the risk to individuals, financial institution and law enforcement agencies. The harm of ML is invisible, but is clearly significant. The harm and threat of ML has obviously indicated the need to have more intensive and effective AML countermeasures in Vietnam. The foremost rationale for the AML countermeasure stems from the need to protect the integrity of financial institutions and disrupt predicate crimes.

\section{Notes}

1. See Nguyen $v$ The Queen [2011] NSWCCA 111 and $R v$ Nguyen [2010] NSWCCA 226.

2. Article 250 of the 1999 Penal Code (Vietnam) denotes the crime of "Harbouring or consuming property derived from criminal activity committed by other persons". The Article 250(1) states that: "Those who without prior promise, harbours or consumes property, fully knowing that it was derived from criminal activity committed by other persons, shall be sentenced to a fine of between five million dong and fifty million dong, noncustodial reform of up to three years or a prison term of between six months and three years".

Article 251 of the 1999 Penal Code refered to the crime of: "Legalizing money and/or property derived from the commision of a crime", and provided that: "Any person using financial and/or banking operators or other transactions, legalize money and/or property derived from the commision of a crime or use such money and/or property to conduct business activities or other economic activities, shall be sentenced to between one and five years of imprisonment).

3. Article 3(1) of the Government Decree No. 74/ 2005/ND-CP on Prevention and Suppression of Money Laundering (Nghi Dinh so 74/2005/ND-CP ve Phong, Chong Rua Tien) provides as follows: “...'[M] oney laundering' shall mean the act of an individual or organization who tries to legalize money and/or property derived from the commission of a crime through the following specific activities: engaging, 
directly or indirectly, in a transaction that involves money and/or property derived from the commission of a crime; acquiring, receiving, possessing, transferring, conversion, assigning, moving, using, moving from and bringing into Vietnam money and/or property derived from commission of a crime; investing in a project, work, contributing money to an enterprise or otherwise trying to conceal, disguise or impede the examination of the true nature, origin, location, movement, or ownership of money and/or property derived from the commission of a crime.."

4. Article 34(1) of the amendment to the 1999 Penal Code (National Assembly, 2009) refers to the crime of ML as followings: "Those who commit one of the following acts shall be sentenced to a prison term of between one and five years:

a) engaging, directly or indirectly, in financial transactions, banking or other transactions that involve money and/or property obtained through the commission of a crime, fully knowing that such money and/or property was obtained through the commission of a crime, for the purpose of concealing the illicit origin of such money and/or property;

b) using such money and/or property, fully knowing that such money and/or property was obtained through the commission of a crime, to conduct business activities or other activities;

c) concealing the information about the origin, true nature, location, movement, or ownership of money and/or property obtained through the commission of a crime; or impeding the examination of such information;

d) commiting one of the acts prescribed in a), b) and c) involving money and/or property, fullyl knowing that such money and/or property was derived from the process of transferring, assigning and conversion of the money and/or property generated from criminal activity”.

5. According to the Mutual Evaluation Report (2009) conducted by the APG (available at http://www.apgml.org/documents/docs/17/Vietnam\%20ME1.pdf), each year from 2006-2008, there were a low number of convictions under the Article 250 of the 1999 Penal Code. The number of conviction under Article 251 of the 1999 Penal Code was also insignificant. Moreover, as of March 2013, the prosecution of money laundering under the amended Article 251 (Article 34 of the amendment to the 1999 Penal Code) has been non-existent. 


\section{References}

AFP (2004), "Two more arrested over Vietnam Airlines fuel scam ", Agence France Presse

Alldridge, P.W. (2008), "Money Laundering and Globalization", Journal of Law and Society, Vol. 35, No. 4, p. 27.

APG (2009), "VIETNAM ME1 (Mutual Evaluation Report on Anti-Money Laundering and Combating the Financing of Terrorism)", available at:

http://www.apgml.org/documents/docs/17/Vietnam\%20ME1.pdf (accessed 20 April 2013).

Bartlett, B.L. (2002), The Negative Effects of Money Laundering on Economic Development, Asian Development Bank.

Chau, H. (2011), "Canh Bao Toi Pham Kieu Mafia Tiem An Tại Viet Nam", available at: http://phapluattp.vn/20110415124042714p0c1013/canh-bao-toi-pham-kieu-mafia-tiem-antai-vn.htm (accessed 4 May 2013).

Croissant, A.B., D. (2007), "Following the Money Trail: Terrorist Financing and Government Responses in Southeast Asia", Studies in Conflict \& Terrorism, Vol. 30, No. 2, pp. 131-56.

Duyne, P.C.v. and Levi, M. (2005), Drugs and Money: Managing the Drug Trade and Crime Money in Europe Routledge, New York.

FATF (2010), Global Money Laundering \& Terrorist Financing Threat Assessment.

FATF (2011), "Laundering the Proceeds of Corruption", available at: http://www.fatfgafi.org/media/fatf/documents/reports/Laundering\%20the\%20Proceeds\%20of\%20Corruptio n.pdf (accessed 21 April 2013).

FATF (2012), "High-risk and Non-Cooperative Jurisdictions", available at: www.fatfgafi.org/topics/high-riskandnon-cooperativejurisdictions/( (accessed 5 May 2013).

Fried, D.J. (1988), "Rationalizing Criminal Forfeiture", Journal of Criminal Law and Criminology, Vol. 79, No. 2, p. 109.

Gainsborough, M. (2003), "Corruption and the Politics of Economic Decentralisation in Vietnam", Journal of Contemporary Asia, Vol. 33, No. 1, p. 15.

Gillespie, J. (2001), "Self-Interest and Ideology: Bureaucratic Corruption in Vietnam", Australian journal of Asian law, Vol. 3, No. 1, p. 36.

Gillespie, J. (Ed.) (2005), Changing Concepts of Socialist Law in Vietnam, ANU E Press

Gilmore, W.C. (1992), International Efforts to Combat Money Laundering, Cambridge University Press Cambridge.

Gilmore, W.C. (1999), Dirty Money: The Evolution of Money Laundering Countermeasures, 2nd edn, Council of Europe, Strasbourg.

He, P. (2010), "A Typological Study on Money Laundering", Journal of Money Laundering Control, Vol. 13 , No. 1, pp. 15-32.

Hopton, D. (2006), Money Laundering : A Concise Guide for All Business, Gower Publishing Limited, Hampshire.

Jeffrey, R. (1997), The Laundrymen - Inside Money Laundering, The World's Third Largest Business, Arcade Publishing, New York.

Johnson, K. (2003), "Goodbye, Godfather", available at: http://www.time.com/time/magazine/article/0,9171,428126,00.html (accessed 5 May 2013).

Lilley, P. (2006), Dirty Dealing: The Untold Truth about Global Money Laundering, International Crime and Terrorism, 3rd edn, Kogan Page Limited, London.

Linh, M. (2008), "Vu tham o tai Cong ty Xang dau hang khong: 14 bị cao hau toa ", available at: http://www.anninhthudo.vn/An-ninh-doi-song/Vu-tham-o-tai-Cong-ty-Xang-dau-hangkhong-14-bi-cao-hau-toa/324817.antd (accessed 3 May 2013).

McDowell, J., Adviser, S.P. and Novis, G. (2001), "The Consequences of Money Laundering and Financial Crime", Economic Perspectives, Vol. 6, No. 2, p. 3. 
Penal Code (Vietnam) Law No. 15/1999/QH10, 21 December 1999, entered into force 1 July 2000

Law on Prevention and Suppression of Corruption (Vietnam) Law No. 55/2005/QH11, 29 November 2005, entered into force 1 June 2006

Law Amending and Supplementing to a Number of Articles of the Penal Code (Vietnam) Law No. 37/2009/QH12, 19 June 2009, entered into force 1 January 2010

Law on Prevention and Suppression of Money Laundering (Vietnam) Law No. 07/2012/QH13, 18 June 2012, entered into force 1 January 2013

President's Commission on Organized Crime (the United States) (2001), The Cash Connection: Organised Crime, Financial Institutions, and Money Laundering, Books for Business New York - Hong Kong.

PV (2003), "Y an tu hinh Truong Van Cam", available at: http://tuoitre.vn/Chinh-tri-xa-hoi/Phapluat/6991/Y-an-tu-hinh-Truong-Van-Cam.html (accessed 4 May 2013).

Sato, Y. (2009), "How to Deal with Corruption in Transitional and Developing Economies: A Vietnamese Case Study", Journal of Financial Crime, Vol. 16, No. 3, p. 9.

Savona, E.U. (2000), Responding to Money Laundering: International Perspectives, Reprint edn, Taylor \& Francis Group.

SGGP (2005), "Phat hien rua tien trong vu an tai cty xang dau HK", available at: http://tuoitre.vn/Kinh-te/80911/Phat-hien-rua-tien-trong-vu-an-tai-cty-xang-dau-HK.html (accessed 3 May 2013).

Stessens, G. (2000), Money Laundering: A New International Law Enforcement Model, Cambridge University Press, Cambridge.

Thanh, H. (2012), "Quyet liet chong toi pham hoat đong theo kieu "xa hoi den"”, available at: http://www.cand.com.vn/vi-VN/xahoi/2012/5/176092.cand (accessed 3 May 2013).

Thuc, P. (2007), "Rua tien bang du an", available at: http://www.sggp.org.vn/SGGP12h/2007/1/81485/ (accessed 3 May 2013).

Transparancy International 'Corruption Index 2012', available at: http://cpi.transparency.org/cpi2012/results/ (accessed 28 April 2013).

TTXVN (2010), "Thi hanh an tu hinh trum ma tuy Trinh Nguyen Thuy", available at: http://dantri.com.vn/c20/s20-412353/thi-hanh-an-tu-hinh-trum-ma-tuy-trinh-nguyenthuy.htm (accessed 3 May 2013).

U.S, T. (2004), "More Than 130 Arrested in International Narcotics and Money Laundering Investigation", available at: http://www.justice.gov/opa/pr/2004/March/04 crm 209.htm (accessed 4 May 2013).

U.S. Department of State (2011), International Narcotics Control Strategy Report (Volume I: Drug and Chemical Control).

U.S. v. Dong Dang Huynh (2011), 420 Fed.Appx. 309.

United Nations Convention against Illicit Traffic in Narcotic Drugs and Psychotropic Substances 20 December 19881582 UNTS 95 (entered into force 11 November 1990) [1988 Vienna Convention].

United Nations Convention against Corruption 31 October 20032349 UNTS 41 (entered into force 14 December 2005) [UNCAC].

US (2010), "Former Nexus Technologies Inc. Employees and Partner Sentenced for Roles in Foreign Bribery Scheme Involving Vietnamese Officials", available at: http://www.justice.gov/opa/pr/2010/September/10-crm-1032.html (accessed 4 May 2013).

WB (2007), "Strengthening World Bank Group Engagement on Governance and Anticorruption", available at: http://siteresources.worldbank.org/PUBLICSECTORANDGOVERNANCE/Resources/GACStrate gyPaper.pdf (accessed 20 April 2013).

WB (2010), "Bui Tien Dung case", available at: http://star.worldbank.org/corruptioncases/node/18638 (accessed 4 May 2013). 
WB (2011), "Migration and Remittances Factbook", available at:

http://siteresources.worldbank.org/INTLAC/Resources/Factbook2011-Ebook.pdf (accessed 28 April 2013).

WB (2013), Corruption from the Perspective of Citizens, Firms, and Public Officials : Results of Sociological Survey The National Political Pulishing House, Hanoi.

\section{Corresponding author}

The author can be contacted at: Chatlenguyen@yahoo.com.vn or

Chat.lenguyen@pg.canterbury.ac.nz 